\title{
ARTICLES
}

\section{The NGOs' Participation in the Proceedings of the International Court of Justice}

\section{Saratoon Santivasa *}

Many international judicial bodies have prescribed the procedures allowing NGOs to participate in the proceedings generally as non-parties as amicus curiae, expert or witness for the purpose of the good administration of justice. These possibilities are well developed in judicial bodies where the nature of proceedings concerns the issues that international law recognizes as the collective interests of the international community. In the International Court of Justice, on the contrary, NGOs do not have such possibility to make contributions as they have done in other international judicial bodies. The development of the elaboration of the texts on the Court proceedings and the restrictive interpretation of these texts reflect the restrictive approach of the Court towards NGOs' participation. The Court should offer the scope to access NGOs since they have legitimate right to represent the views of international civil society in an international democratic process and can contribute to assist the Court to protect the collective interest of the international community.

\section{Keywords}

Non-Governmental Organizations, International Judicial Proceedings, International Court of Justice, Amicus Curiae, Administration of Justice

* Assistant Professor of Law at Chulalongkorn University, Thailand, LL.B. (Chulalongkorn), DEA en Droit International (Paris II), Docteur en Droit (Paris II). The author may be contacted at: saratoon.s@chula.ac.th /Address: Faculty of Law Chulalongkorn University, Phayathai Road, Pathumwan, Bangkok 10330, Thailand. 


\section{Introduction}

Non-governmental organizations ("NGOs") are legal persons established under domestic private law and as such have no international personality. Nonetheless, they play important roles in international law and have certain rights, although they cannot be treated equal to States or intergovernmental organizations. While their status is limited to being actors or even observers in international forums, their contribution to the development of international law is undeniably remarkable. Over the past decades, international NGOs are increasingly taking part in various steps of the international legal order such as elaboration of rules, law enforcement and litigation. ${ }^{1}$ However, NGOs have not yet been recognized as a legal person under international law ${ }^{2}$ as well as domestic law. 3

Despite the lack of international legal personality, NGOs have established regular collaboration with inter-governmental organizations. In the last decade, some NGOs have achieved informal and formal access to the international decision-making process and have became non-negligible partners of States and inter-governmental organizations on various issues, particularly when it happens to be in the common interest of the international community. They are actively involved in the international treaty making-process and significantly engaged in the enforcement of international law by monitoring State compliance with international obligation.

In principle, the only subject under international law that can generally initiate cases

1 A.-K. Lindblom, Non-Governmental Organizations in International LaW passim (2005). See also A. Bianchi, NonState Actors and International LaW passim (2009); I. Rossi, Legal Status of Non-Governmental Organizations IN INTERNATIONAL LAW passim (2010).

2 A legal personality in international law has been recognized in case of the International Committee of Red Cross ("ICRC"). The ICRC has rights under not only international law, but also international obligations. This international legal personality has been clearly recognized by the 1966 Agreement concluded between Switzerland and International Federation of the Red-Cross and the Red Crescent Societies. This international legal personality has been reflected by the fact that the ICRC has capacity to conclude the international agreements with States and rights to legation in international relations. Moreover, the ICRC has capacity to assert its claims directly against others subjects of international law. See A. Escorihuela, Le Comité International de la Croix Rouge comme Organization sui generis? Remarques sur la. Personnalité Juridique Internationale du CICR, 105 Revue Generale DE DroIT International Public ("RGDIP”) 598-602(2001). P.-M. Dupuy, L'Unité de l'Ordre Juridique International, 297 Recueil des Cours de l'Académie de Droit International de la Haye/Collected Courses of the Hague Academy of International Law ("RCADI") 118(2002). See also C. Dominicé, Accord de Siège Conclu par le Comité International de la Croix Rouge avec la Suisse, 99 RGDIP 5-36 (1995).

3 Special Rapporteur Giorigo Gaja, when defending the scope of the ILC study on the responsibility of international organization, explained that NGOs were not included in the study because it considers the organizations that were already subjects of international law and as such bound by obligations imposed on them by international law. See G. Gaja, First Rapporteur on Responsibility of International Organizations, U.N. Doc. A/CN.4/532, Mar. 26, 2003. 
before the international judicial bodies is the 'State.' In the case of NGOs, 4 accordingly the fact that NGOs are not subject of international law restricts considerably their access to the international jurisdiction. 5 The practice showed, however, that the possibility of NGOs to accede to the international jurisdictions is not necessarily based on their personality criteria. It is indeed their intention to accede to the international jurisdictions that will transcend the legal personality barrier. Their willingness must not be seen as an act being conditioned by the consent, but by the impetus given by themselves. NGOs should not be limited to the cases where States have offered them an opportunity to access to an international jurisdiction. ${ }^{6}$ This is the NGO's locus standi based on which an NGO has the right either to become party to the litigation or to be heard by the judges during the proceedings. ${ }^{7}$ As a result, NGOs can participate in the international proceedings at their own initiative to suggest a rational consistent with its own view as amicus curiae. 8 In the case of the amicus curiae, their role is non-party intervention which has an objective to offer to the court a certain point of view on legal issue or on facts in the area of their own specialization. NGOs thus become friends of the courts who may be allowed to intervene in the court proceedings where it is considered appropriate.

In the scope of their interest like human rights, environmental protection, and humanitarian law, NGOs would get involved in legal issues which were raised in different cases and would assist the court by presenting their observations. Acting as amicus curiae, NGOs are not interested actors in a particular case per se, but serve the law and assist the court. Their interest is to propose to the judges a concrete legal point of view, and their role is limited to contribute this end by their expertise or by providing available information in the spirit of independence and objectivity. ${ }^{9}$

Simultaneously, NGOs may participate in the court proceedings when they are appointed by a court as an expert. The locus standi for NGOs to use for their participation, as amicus curiae or as expert, in the international jurisdictions exists more or less in the statutes and rules of international judicial bodies, varying from one to another.

It is worth noting that the participation of NGOs in the judicial proceeding is

4 T. Treves et AL. (EDS.), Civil Society, International Courts and Compliances Bodies (2005). See also I. SOUMY, L'aCcÈs des ORganisations Non Gouvernementales Aux Juridictions Internationales passim (2008); L. Bartholomeusz, The Amicus Curiae before International Courts and Tribunals, in Bianchi, supra note 1, at 253-330; Lindblom, supra note 1, at 218-365; Rossi, supra note 1, at 241-337; D. Shelton, The Participation of Nongovernmental Organizations in International Judicial Proceedings, 88 AM. J. INT' L. L. $611-642$ (1994).

5 Soumy, id. at 17.

$6 \quad$ Id.

7 R. Ranjeva, Les NGO et la Mise en CEuvre du Droit International, 270 RCADI 50 (1997).

B. GARNER (ED.), BLACK's LaW Dictionary (9th ed. 2004).

9 Olivier de Shutter, Sur l'Emergence de la Société Civile Internationale: le Rôle des Associations devant la Cour Européenne des Droits de l'Homme, 7 EuR. J. INT'L L. 379-385 (1996). 
different from their participation on the basis of consultative status in the international organizations such as the UN Economic and Social Council ("ECOSOC"). 10 In exercising their consultative role with the international organizations, NGOs participate in the law-making and the law-enforcement process in the multilateral forum. ${ }^{11}$ Their rights and obligations depend on their particular status recognized by the international organization whom they have relationships with.12 When they participate in a judicial proceeding, as amici or as expert, however, their role is to help the judges for the proper administration of justice in law-enforcement by judicial means. Therefore, their role in the judicial proceeding can be considered as the prolongation of their consultative role on another front.

In the International Court of Justice ("ICJ") which is open principally to States and inter-governmental organizations, NGOs could traditionally accede to the Court proceedings. However, the Court practices show that the role of an NGO to protect the common interest of the international community in the ICJ proceedings has faced a number of challenges posed by the legal instruments related to the Court proceedings and the Court's own discretion. 13

The main purpose of this research is to analyze these legal instruments for NGOs to participate in the proceedings of the ICJ. This paper is composed of five parts including Introduction and Conclusion. Part two will overview the NGOs' approach to international proceedings. Part three will discuss the possibility of NGOs' participation in the ICJ proceedings. Part four will evaluate the legitimacy of the NGOs' participation in the ICJ proceedings.

\section{The NGOs' Access to International Proceedings: An Overview}

The present development of international law depicts an increasing participation of

10 U.N. Charter art. 71. It reads: "The Economic and Social Council may make arrangement for consultation with nongovernmental organizations which are concerned with maters within its competence. Such arrangement may be made with international organizations and, where appropriate, with national organizations after consultation with the Member of the United Nations concerned."

11 For the legal aspects of consultative relationships between the NGOs and the ECOSOC, see B. SIMMA (ED.), THE CHARTER OF THE UNITED NATIONS: A COMMENTARY, 902-915 (1995).

12 Id. at $908-913$

13 C. Santulli, Droit Du Contentieux International 305 (2005). The author explains that: "La juridiction international a, sauf disposition contraire, une discrétion complète pour recevoir au titre de la preuve tous les éléments qu'elle juge pertinent." 
NGOs in international and regional judicial proceedings. Various jurisdictions have granted rights to NGOs to initiate or to take part in the judicial proceedings. In very rare cases, NGOs participate as a party; in others, they have access to the court as non-party such as amicus curiae, expert or witness.

\section{A. International Criminal Court and Tribunals ${ }^{14}$}

The International Criminal Court ("ICC") has jurisdiction to prosecute individuals for the most serious international crimes, namely, the crime of genocide, crimes against humanity, war crimes and crimes of aggression. 15 The ICC may exercise its jurisdiction when one or more crimes under its Statute are referred to the Prosecutor of the Court by a State party or by the United Nations Security Council, or when the Prosecutor initiates investigation proprio motu. In the later case, Article 15 (2) of the Rome Statute and Article 104 of the ICC Rules of Procedure and Evidence provide that the Prosecutor may initiate investigations and seek information from States, organs of the UN, inter-governmental organizations or non-governmental organizations. NGOs' documents are thus officially referred to as an important source of information and play a crucial role in influencing the Prosecutor to open an investigation. The Congo case in 2004 can be cited here as a glaring example in this regard. 16 Similar provisions exist in Article 18(1) of the Statute of the International Criminal Tribunal for Former-Yugoslavia ("ICTY")17 and Article 17(1) of the Statute of the International Criminal Tribunal for Rwanda ("ICTR").18

Moreover, it is interesting that the ICC Statute allows NGOs to appear before the Court as victims. ${ }^{19}$ Being recognized as victim, they are holding a right to speak and can

14 This article refers only to the International Criminal Court and the ad hoc International Criminal Tribunals for former Yugoslavia and Rwanda. For the Special Court for Sierra Leone, see, e.g., Rossi, supra note 1, at 302-304. For The East Timor Special Panels for Serious Crimes, see Chiara Ragni, NGOs and The East Timor Special Panels for Serious Crimes, in Treves et al. (eds.), supra note 4, at 129-142.

15 ICC Statute art. 5.

16 See The International Criminal Court; How Nongovernmental Organizations Can Contribute to the Prosecution of War Criminals, (Sept. 2004), available at http://www.iccnow.org/documents/HRW_iccProsecutions_0904.pdf (last visited on Nov. 1, 2012).

17 It reads: "The Prosecutor shall initiate investigations ex-officio or on the basis of information obtained from any source, particularly from Governments, United Nations organs, intergovernmental and non-governmental organization. The Prosecutor shall assess the information received or obtained and decide whether there is sufficient basis to proceed."

18 It reads: "The Prosecutor shall initiate investigations ex-officio or on the basis of information obtained from any source, particularly from governments, United Nations organs, intergovernmental and non-governmental organization. The Prosecutor shall assess the information received or obtained and decide whether there is sufficient basis to proceed."

19 According to Article 85 of the Rules of Procedure and Evidences, 'victims' means natural persons who have suffered harm from any crime within the Court jurisdiction and may include organizations and institution that have sustained direct harm to any of their property which is dedicated to religion, education, art or science or charitable purpose, and to their historic monuments, hospitals and other places and objects for humanitarian purpose. 
exercise rights resulting from this status. Victims may provide information and evidence which are necessary for the investigation. They have the right to be heard before the ICC Chambers at the pre-trial, during the proceedings and at the appeal stage. 20 This right, however, is subject to the discretion of the Court according to Article 68(3) of the ICC Statute which provides that the Court can allow NGOs to present their views if it is appropriate and if it is not prejudicial to the right of the accused and a fair and impartial trial. 21

NGOs can also participate in the Court proceedings as amicus curiae. Article 44 of the Statute provides that the ICC may, in exceptional circumstance, employ the expertise personnel offered by NGOs to assist with works of any organ of the Court. In addition, Rule 103(1) of the ICC's Rule of Procedure states that:

At any stage of the proceedings, a Chamber may, if it considers it desirable for the proper determination of the case, invite or grant leave to a State, organization or person to submit, in writing or orally, any observation on any issue that the Chamber deems appropriate.

The ICC has received many requests from NGOs to grant their amicus curiae submissions. ${ }^{22}$ However, the Court has been cautious in granting leave to NGOs to submit amicus curiae briefs. 23 The Registrar has pointed out that the principal characteristic of amicus brief is the impartiality of the intervening person. ${ }^{24}$ In addition, jurisprudence establishes the relevant conditions that amicus brief is justifiable when the intervention: (1) is desirable for the proper determination of the case; 25 (2) relates to the

20 According to Article 93 of the Rules of Procedure and Evidence, a Chamber (Pre-Trial Chamber, Trial Chamber or Appeal Chamber) may seek the views of victims on any issue. In particular, a Pre-Trial Chamber may seek the views of victims when it reviews a decision of the Prosecutor not to proceed with an investigation at the request of a State (Rule 107) or by its own initiative (Rule 109).

21 It reads: "Where the personal interests of the victims are affected, the Court shall permit their views and concerns to be presented and considered at stages of the proceedings determined to be appropriate by the Court and in a manner which is not prejudicial to or inconsistent with the rights of the accused and a fair and impartial trial. Such views and concerns may be presented by the legal representatives of the victims where the Court considers it appropriate, in accordance with the Rules of Procedure and Evidence."

22 See the list of the requests for leave to submit amicus curiae briefs at the International Criminal Court, available at http://www.icc-cpi.int/Menus/ICC/Search?qt=Request+leave+to+submit+Amicus+Curiae+\&x=29\&y=11\&la=en (last visited on Nov. 1, 2012).

23 A large number of amicus briefs submitted to the ICC had been rejected. Only few have been granted to leave file. In the case of the Prosecutor v. Jean-Pierre Bemba Gombo, e.g., Amnesty International and the Women's Initiatives for Gender Justice were granted leave to file amicus curiae briefs. Prosecutor v. Jean-Pierre Bemba Gombo, ICC-01/0501/08, Decision on Request for Leave to Submit Amicus Curiae Observations Pursuant to Rule 130 of the rules of Procedure and Evidence (July 17,2009), at 7.

24 See the observation of the Registrar in Prosecutor v. Thomas Lubanga Dyilo, ICC-01/04/06 (June 7, 2007), at 6-7.

25 See Registrar referred to Prosecutor v. Kallon, Case No. SCSL-03-07-PT; Decision of the Application for Leave to 
legal arguments which are principal legal points;26 and (3) must clarify a new and complex legal issue on the basis of an acknowledged expertise on the question which has been raised. Otherwise, the brief should be rejected.

Both the ICTY and the ICTR allow amicus curiae briefs by NGOs. The Rule of Procedure and Evidence of either jurisdiction contains identical provision stipulating that the trial and appeals chambers may invite or grant NGOs leave to file an amicus briefs. 27 For example, the ICTY received various requests from NGOs to intervene as amicus curiae in the Tadić case ${ }^{28}$ and the Blaškić case ${ }^{29}$ to provide advices on important issues of general and criminal international law. The ICTR granted leave to NGOs for the same reason the Kanyrukiga case ${ }^{30}$ and in the Akayesu case. ${ }^{31}$ Nevertheless, the practices of both jurisdictions seem to indicate that the position of each tribunal is not quite the same. The ICTY has used amicus curiae widely. In certain circumstances, however, when the Tribunal has gone beyond the term of Article 74 of the Rules, for example in Milošević case, 32 the Tribunal has granted the amici to NGOs certain capacity similar to that of the parties, making thus the boundary between amicus curiae and parties unclear. ${ }^{33}$ Moreover, the ICTY has seemed to be more open to amicus briefs from NGOs since the beginning, whereas the ICTR refused to grant leave to NGOs to file amicus curiae briefs in the initial years, but has become more opened to amicus curiae submission by NGOs recently. ${ }^{34}$

\section{B. The International Tribunal for the Law of the Sea}

The International Tribunal for the Law of the Sea ("ITLOS") is a judicial body

Submit Amicus Curiae Briefs (July 17, 2003), at 170.

26 See Registrar referred to Prosecutor v. Semanza, ICTR-97-20-T; Decision on the Kingdom of Belgium's Application to File an Amicus Curiae and on the Defence Application to strike out the Observation of the Kingdom of Belgium Concerning the Preliminary Response to the Defence (Feb. 9, 2001).

27 See Rule 74 of Rule of Procedure and Evidence of the ICTY and Rule 74 of Rule of Procedure and Evidence of the ICTR.

28 Prosecutor v. Duško Tadić, Case No. IT-94-1-T, Opinion and Judgment (May 7, 1997), at 2-15.

29 Prosecutor v. Tihomir Blaškić, Case No. IT-95-14-T, Orders Granting Leave to Appear as Amicus Curiae (Apr. 11, 1977).

30 Prosecutor v. Kanyarukiga, Case No. ICTR-2002-78-I, Decision on Difference Request to Grant Amicus Curiae Status to Four Non-governmental Organizations (Feb. 22, 2008).

31 Prosecutor v. Akayesu, Case No.ICTR-94-4-T, Judgment (Sept. 22, 1998). In this case, a coalition of more than 45 human rights NGOs submitted an amicus curiae brief to the ICTR and urged also the Prosecutor to include rape and other sexual crimes in the indictment. See Bartholomeusz, supra note 4, at 245-247.

32 Prosecutor v. Slobodan Milošević, Case No. IT-02-54, Order Inviting Designation of Amicus Curiae, (Nov. 23, 2001).

33 Bartholomeusz, supra note 4, at 243-253; Lindblom, supra note 1, at 301-317; Rossi, supra note 1, at 289-302. See also S. Williams \& H. Woolaver, The Role of the Amicus Curiae before the International Criminal Tribunals, 6 InT'L CRIM. L. Rev. 151-189 (2006).

34 Rossi, supra note 1 , at 329. 
established under Part XI and Annex VI of the United Nations Convention on the Law of the Sea 1982("UNCLOS"). Part XI also constitutes the Seabed Disputes Chamber of the ITLOS which has compulsory jurisdiction over some categories of disputes related to activities in the seabed. The access to the Chamber is broader than that of the Tribunal; the non-States entities are allowed to bring cases before the Seabed Disputes Chamber of the ITLOS. However, NGOs are not mentioned among the non-State actors ("NSAs") before the latter body. 35

In the advisory proceedings, under Article 191 of the UNCLOS and under Article 131 of the Rules of the Tribunal, the right to request an advisory opinion cases is limited to States and inter-governmental organizations.

Regarding amicus curiae, Article 84 and Article 133 of the ITLOS Rules of Procedure respectively providing contentious proceedings and advisory proceedings state that the Tribunal and the Chamber may request or permit the information submission only from inter-governmental organizations. It is worth mentioning here an interesting development in an advisory opinion by the International Seabed Authority regarding "Responsibilities and Obligations of States Sponsoring Persons and Entities with respect to Activities in the International Seabed Area" (Case no.17) 36 where Greenpeace and the World Wildlife Fund for Nature ("WWF"),37 as non-governmental organizations, were seeking leave to file written submissions and make oral submissions. However, these amicus briefs were considered part of the case filed by the Seabed Dispute Chamber. 38

\section{The WTO Dispute Settlement Procedure}

The dispute settlement procedure of the World Trade Organization ("WTO"), Dispute Settlement Understanding ("DSU”), allows only the WTO member States to participate

35 Articles 187 and 285 of the UNCLOS and Article 20 of the ITLOS Statute provides the Standing requirements before the ITLOS and the Seabed Dispute Chamber. States, the international Seabed Authority, privates companies and individuals can be the party before the Seabed Dispute Chamber. In the ITLOS, the possibility for the NSAs to appear before the ITLOS is not clear; it depends on the interpretation of Article 20 of the Statute. See P. Gautier, NGOs and the Law of the Sea, in Treves et al. (eds.), supra note 4, at 233-242. As for the advisory jurisdiction, under Article 191 of the United Nations Convention on the Law of the Sea and under the Rules of the Tribunal art. 131, participation in advisory opinion cases seems to be limited to States and intergovernmental organizations.

36 See Responsibilities and Obligations of States Sponsoring Persons and Entities with respect to Activities in the International Seabed Area, Advisory Opinion, Seabed Dispute Chamber of the International Tribunal for the Law of the Sea (Feb. 1, 2011) available at http://www.itlos.org/fileadmin/itlos/documents/cases/case_no_17/ adv_op_010211.pdf (last visited on July 28, 2012)

37 Greenpeace International and the WWF submitted a petition requesting the ITLOS to permit them to intervene and to accept their joint amicus curiae brief as part of the pleadings in this case. Both the petition and the amicus curiae brief may be found at Greenpeace International website, available at http://www.greenpeace.org/international/en/ System-templetes/Serch-results/?all=itlos\%20amicus (last visited on Sept. 10, 2012).

38 See ITLOS official website, available at http://www.itlos.org/index.php?id=109 (last visited on July 28, 2012). 
as parties in dispute settlement regarding their rights and obligations under the WTO agreements. Upon requests of the complaining party, a Panel is set up by the Dispute Settlement Body ("DSB") to resolve the conflict. Appeals can be brought before a standing Appellate Body.

The problem concerning the NGOs' participation in the WTO dispute settlement system has relied on the interpretation of Article 13 of the DSU, which provides that:

1. Each panel shall have the right to seek information and technical advice from any individual or body which deems appropriate...;

2. Panels may seek information from any relevant source and may consult experts to obtain their opinion on certain aspects of the matter. With respect to a factual issue concerning scientific or other technical matter raised by a party to a dispute, a panel may request an advisory report in writing from an expert review group...

The Panels and the Appellant have received amicus curiae briefs on various occasions. In the US-Shrimp case, 39 two joint amicus briefs were submitted to the Panel by NGOs. The Panel refused to take into account these non-requested documents from NGOs for the reason that it would be incompatible with the provision of the DSU. The Appellate Body reversed the Panel's view, stating that: "A panel has the discretionary authority either to accept and consider or to reject information and advise submitted to it, whether requested by a panel or not." 40 A large number of member States expressed their concerns over the Appellate Body's expansive interpretation of Article 13 of the DSU.41 Although the possibility for NGOs to submit amicus briefs is officially recognized, the subsequent cases 42 have shown that both Panels and the Appellate Body, while maintaining their discretionary authority to accept and consider non-requested briefs, have refused, in most instances, to accept and consider amicus curiae briefs because these briefs were not necessary in renderings its decisions. 43

\section{The Court of Justice of European Union}

In the past, NGOs could not be parties to a judicial proceeding unless they were either

39 See United States-Import Prohibition of Certain Shrimp and Shrimp Products, Report of the Panel, WT/DS58/R, May 15, 1998, available at http://www.wto.org/english/tratop_e/dispu_e/58r01.pdf (last visited on July 28, 2012).

40 See United States-Import Prohibition of Certain Shrimp and Shrimp Products, Report of the Appellate Body, WT/DS58/AB/R, Oct. 12, 1998, ๆ 101.

41 Bartholomeusz, supra note 4, at 257.

42 For details on these cases, see Rossi, supra note 1, at 304-307; Lindblom, supra note 1, at 322-327.

43 B. Stern, L'Intervention dans le Contentieux de l'OMC, 107 RGDIP 271 (2003). 
directly addressed by an EU decision, or directly and individually concerned by an EU decision or regulation. Later, the Lisbon Treaty introduced a provision expanding the right to challenge the EU measures. Article 263(4) of the Lisbon Treaty provides that:

Any Natural or Legal person may...institute proceedings against an act addressed to that person or which is of direct and individual concern to them, and against a regulatory act which is of direct concern to them and does not entail implementing measures. 44

This article, while maintaining the direct and individual concern principle in order to challenge the EU acts, provides that, in the case of regulatory acts, the individual concern criteria is not required. Through this new rule of judicial review, NGOs may be recognized as having locus standi as party to challenge the regulation to protect a collective interest. 45

According to Article 40 of the Statute of the European Court of Justice ("ECJ") and Article 93(1) of the Rules of the ECJ, any person establishing an interest in the result of the case submitted to the ECJ may intervene, except in the case between member States and/or institutions of the EU. An application to intervene shall be limited to supporting the form of order sought by one of the parties. The intervention must show direct and concrete interest in the outcome of the case. It is worth noting that under these provisions the intervening persons seek to protect their own interest in the dispute, not the interest of the proper administration of justice. This intervention is not thus amicus curiae. In various instances, NGOs attempted to intervene under Article 40 of the Statute of the ECJ, but were rejected by the Court simply because they could not have shown a direct interest established within the field of their objective. 46

\section{E. The European Court of Human Rights}

Not until the entry into force of the 11th Additional Protocol to the European Convention on Human Rights ("ECHR") in 1998, the individuals and NGOs have locus standi as parties before the European Court of Human Rights ("ECtHR"). Article 34 of the ECHR provides that the Court "may receive application from person, nongovernmental organization or group of individuals claiming to be victim of a violation

\footnotetext{
44 See Information and Notices in 50 OfFICIAL J. EUR. UnIon (2007), available at eur-lex.europa.eu/LexUriServ/ LexUriServ.do?uri=OJ:C:2007:306:FULL:EN:PDF (last visited on Sept. 10, 2012).

45 Rossi, supra note 1, at 273; Soumy, supra note 4, at 402-405.

46 See, e.g., The Autonomous Region of the Azores v. Council, 2004 European Court Reports ("ECR") II-02153, recited in Rossi, id. at 314.
} 
by one of the High Contracting Parties..." NGOs may, therefore, institute case before the Court as victim itself 47 or as representative of victim 48 and excluding, thus, an actio popularis challenge. 49

Article 36(2) of the Convention provides that: "The President of the Court may, "in the interest of the proper administration of Justice, invite...any person concerned who is not the applicant to submit written comments or take part in hearings." The European Court of Human Rights calls this intervention as "third party intervention." The Court regularly and extensively accepts and relies on documents provided by NGOs and the text of judgments generally refers to NGOs' interventions, as well.50

\section{F. The Inter-American Court of Human Rights}

The American Convention of Human Rights of 1969 ("ACHR") establishes human rights protection regime by allowing different categories of petitioners to submit petitions on behalf of victims. 51 Under Article 44 of the ACHR and Article 23 of the Rule of Procedure of the Inter-American Commission on Human Rights, any person or group of persons or non-governmental entities legally recognized in one or more of the member States of the Organization of American States may submit petition to Commission, on their own behalf or on behalf of third persons, against any member of the Organization who violates its human rights obligations contained in the Convention and in the American Declaration of the Rights and Duties of Man. However, right to submit a petition for NGOs appears to be limited in a number of aspects. First, NGOs may exercise this right before the Commission and not before the Inter-American Court of Human Rights. Second, NGOs may not file complaint as victim since the concept of victim under the Convention refers to individuals. Third, NGOs must be legally recognized in one or more member States. 52

On the other hand, the amicus curiae have been extensively accepted both in the contentious and advisory proceedings. Article 45(1) of the Rules of Procedure provides that the Court may, proprio motu, obtain any evidence it considers helpful from any person whose evidence, statement, or opinion it deems to be relevant. Even this provision does not mention the non-requested amicus briefs; this provision has been

\footnotetext{
47 Conka and Others v. Belgium, App. No. 551564/99 (2001). The Ligues des Droits de l'Homme could not claim since they were not themselves victim of violation.

48 Yusupova and Others v. Russia, App. No. 5428/05 (2009).

49 Lindblom, supra note 1, at 251; Rossi, supra note 1, at 276.

50 N. Vajic, Some Concluding Remarks on NGOs and the European Court of Human Rights, in Treves et al. (eds.), supra note 4, at 93-104.

51 M. Pinto, NGOs and the Inter-American Court of Human Rights, in Treves et al. (eds.), supra note 4, at 47-56.

52 Id. at $51-53$.
} 
used mutatis mutandis as legal basis for such briefs. 53

\section{G. The African Court of Human Rights and Peoples' Rights}

Established by the Protocol to the African Charter of Human rights and Peoples' Rights 1988, the African Court of Human Rights and Peoples' Rights ("AFCHRP") has contentious and advisory jurisdiction. Under Article 3 of the African Charter, the Court has contentious jurisdiction on all disputes submitted to it concerning the interpretation and application of the OAU Charter and Protocol as well as the human rights instrument ratified by the States concerned. According to Article 5(3) and Article 34(6), NGOs with observer status before the African Union Commission can bring cases directly to the Court if the State against which has made a declaration accepting this possibility at the time of its ratification; only five of twenty-six member States have made such declaration as of now. 54

Regarding the advisory jurisdiction, Article 4 of the Protocol and Rule 68(1) of the Rule of the Court specify that an African Organization recognized by the African Union may request advisory opinions. The recognized NGOs may thus initiate advisory proceedings by using this provision as legal basis.

Rule 45(1) of the Rule of the Court provides that: "The Court may, inter alia, decide to hear ... in other capacity [other than witness or expert], any person whose evidence, assertions or statements it deems likely to assist in carrying its task." By means of this Rule, the Court has recently granted the Pan-African Lawyers Union ("PALU") request to participate as amicus curiae in the case of African Commission on Human Rights and Peoples' Rights v. The Great Socialist Libyan People's Arab Jamahiriya.55

The overview has demonstrates that NGOs have been permitted to participate in several international and regional judicial courts and tribunals. The Statute and Rules of Procedure of each judicial body provide the locus standi for NGOs' roles in each jurisdiction as either party or non-party. Since NGOs do not have international legal personalities, participation as party is very limited and can be considered as exceptional. On the other hand, the participation in the international proceedings as non-party is remarkable. It can be observed that the trend goes toward a permissive approach as

53 Id. at 55.

54 Five States are Burkina Faso, Malawi, Mali, Tanzania and Ghana. See List of Countries Which Have Ratified/Acceded to the Protocol, available at http://www.africain-court.org/en/images/documents/Court/Statute\% 20ACJHR//Statutes\%20of\%20the\%20Ratification\%20Process\%20of $\% 20$ the $\% 20$ Protocol\%20Establishing\%20the $\% 20$ Afric ain\%20Court.pdf (last visited on July 28, 2012).

55 See The Court's Order, available at http://www.africain-court.org/en/images/documents/Order-Files/orderamicus.pdf (last visited on July 28, 2012). 
either amicus curiae or expert, particularly, in the circumstance where the protection of collective interest is at stake.

\section{The NGOs' Access to the Proceedings of the International Court of Justice}

Unlike the other international judicial bodies mentioned above, the Statute of the International Court of Justice ("ICJ") does not provide for the legal standing of NGOs to the Court proceedings as party. It is clear that the only entities with international personality can go before the ICJ. Access to the ICJ is restricted to States in contentious cases 56 and, to a lesser extent, to the international organizations for advisory opinion in accordance with the United Nations Charter ${ }^{57}$ and the Statute of the ICJ.58 Nevertheless, the possibility of NGOs to participate in the Court proceedings is not nonexistent. The provisions related to the Court procedure provide locus standi for NGOs to participate as amicus curiae or expert. These options rely fundamentally on the discretion of the Court.

\section{A. Contentious Proceedings}

In the contentious proceedings, Article 34(1) of the ICJ Statute provides that: "Only States may be parties in cases before the court." In addition, a third-party State may intervene in the contention proceedings if it has an interest of a legal nature which may be affected by the decision in the case, 59 or if it is party to the Conventions concerned in the case which has been notified by the Registrar. 60

The possibility for NGOs to participate in the contentious proceedings is mentioned neither in the Statute nor in the Rules of Procedure of the ICJ. However, some provisions have triggered a debate on this question. Article 34(2) and (3) of the Statute provide that:

57 U.N. Charter art. 96. It reads: "1. The General Assembly or the Security Council may request the International Court of Justice to give an advisory opinion on any legal question. 2. Other organs of the United Nations and specialized agencies which may at any time be so authorized by the General Assembly, may also request advisory opinions of the Court on legal questions arising within the scope of their activities."

58 ICJ Statute art. 65, 1 1. It reads: "1. The Court may give an advisory opinion on any legal question at the request of whatever body may be authorized by or in accordance with the Charter of the United Nations to make such request."

59 Supra note 56, art. 62(1).

$60 \quad$ Id. art. 63. 
2. The Court, subject to and in conformity with its Rules, may request of public international organizations information relevant to case before it, and shall receive such information presented by such organizations on their own initiative.

3. Whenever the construction of the constituent instrument of a public international organizations or of an international convention adopted there-under is in case before the Court, the Registrar shall so notify the public international organizations concerned and shall communicate to it copies of all the written proceedings.

Concerning the wording used in the ICJ Statute, the term "public international organization" is analyzed in details by Dinah Shelton. According to her, it is not clear that the Article 26 of the PCIJ Statute which is the precedent for the Article 34 of the ICJ Statute should be considered a precedent restricting the term "public international organization" to institution that are only composed of, or certain States represented by, governments because the International Labour Organization that had access to the PCIJ in the contentions proceedings under the Article 26 of the PCIJ Statute is not solely an international organization of States but a tripartite organization, composing of States and non-States membership. 61

In the Asylum case, 62 the International League for the Rights of Man requested leave from the ICJ to present information relevant to the case according to Article 34(2) of the Statute. The Registrar rejected this request to participate in the Asylum case, explaining that the League was not categorized as "public international organization." 63 Some writers have proposed that the interpretation of the term "public international organizations" should cover "international public interest organizations" 64 in order that NGOs could be accepted. This interpretation was apparently not favored by the Court since the provision of the Rules of the Court regarding the contentious proceedings as it has been amended later; the term "public international organization" refers to an intergovernmental organization." 65

The participation of NGOs in the Court proceedings can be considered possible but indirect. In certain circumstance, their briefs have been integrated into a party's Memorial; by this way, NGOs' briefs can be part of the official document in the proceedings. In the Gabcikovo-Nagymaros Project case66 and the Armed Activities on the

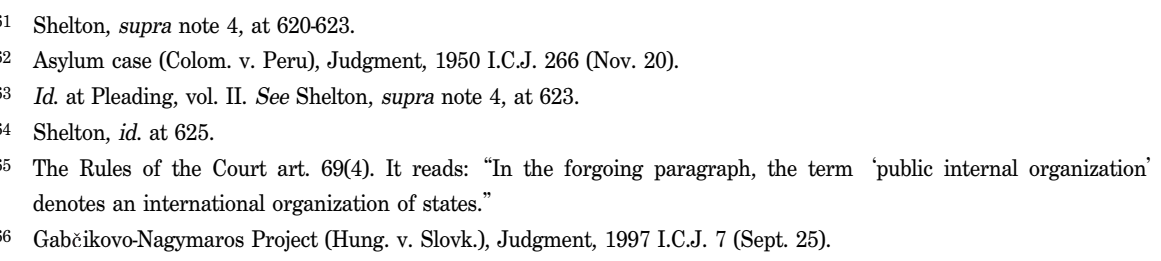


Territory of Congo case, 67 various documents prepared by NGOs were referred to as part of the annexes to the Memorials of the parties. 68 In this connection, Judge Shahabudden has rightly pointed out in another occasion that: "An amicus curiae is limited to his essential function as a friend of the court, as distinguished from being a friend of the accused." 69 Literally, the term amicus curiae means friend of the Court, whose interest to act cannot be assimilated to the interest of a party to a dispute. As a result, NGOs appeared in these cases to be amicus of a party instead of that of the Court.

Another basis for NGOs to submit information to the Court in the contentions proceedings is when they are appointed as experts. It is worth noting that the status of expert is different from amicus curiae. Contrary to the amicus curiae that intervene in the Court proceedings by making the request to the Court, an expert participates in the proceedings by the Court invitation. 70 An NGO can submit information to the Court in the contentions proceedings on the basis of Article 50 of the ICJ Statute, according to which the Court may entrust any individual, body, bureau, commission, or other organization that it may select, with the task of carrying out an inquiry or giving an expert opinion. The wording used in the article is clear and cover all kind of entities; it seems not to be subject to interpretation, which may lead to restrict the participation of NGOs as experts. However, the ICJ has rarely invoked Article 50 of its Statute to appoint an expert.71 Apart from the expert appointed by the Court, NGOs can be heard as experts or witnesses on the request of one of the parties pursuant to Articles 57 and 63 of the Rules of the Court. They may be called if other party makes no objection.

\section{B. Advisory Proceedings}

In the context of the advisory proceedings, there is no provision in the ICJ Statute that

67 Activities on the Territory of the Congo (Congo v. Uganda), Judgment, 2005 I.C.J. 168 (Dec. 19).

68 See, e.g., Judgement: Case concerning the Gabčikovo-Nagymaros Project - (Hungary/Slovakia), available at http://www.sc-sl.org/scsl/Public/SCSL-03-11-Fofana/SCSL-03-11-PT-070/SCSL-03-11-PT-070-XIV.pdf; Case concerning Armed Activities on the Territory of the Congo (Democratic Republic of the Congo v. Uganda), available at http://www.icj-cij.org/docket/files/116/10455.pdf

69 Prosecutor v. Miloševič, Case No.IT-2-54-AR73.6, Decision on the interlocutory appeal by the amicus curiae against the Trail Chamber Order concerning the presentation and preparation of the defense case (Jan. 20, 2004). See Separate Opinion of Judge Shahabuddeen at $\uparrow 15$.

70 Soumy, supra note 4 , at 202.

71 The ICJ exercised its power under Article 50 of its Statute only in two cases. In the Corfu Chanel case, the Court commissioned naval experts to evaluate visibility from the Albanian coast in order to verify the United Kingdom's claim. See Corfu Chanel (U.K. v. Alb.), 1947-48 I.C.J. 124 (Dec. 17, 1948), available at http://www.icjcij.org/docket/files/1/1669.pdf (last visited on July 28, 2012). In the Gulf of Maine case, the Court, upon a joint request of the Parties, appointed an expert in respect of technical matters and in preparing the description of the maritime boundary and the charts. See Delimitation of the Maritime boundary in the Gulf of Maine Area (Can. v. U.S.), 1984 I.C.J. 246 (Oct. 12). 
explicitly mentions the possible participation of NGOs in the advisory proceedings as amicus curiae. Article 66 of the Statute should be taken into account as the starting point of the analysis. Article 66(2) and (4) of the ICJ Statute provide that:

2. The Register shall..., notify any state entitles to appear before the Court or international organization considered by the Court, or, should not be sitting, by the President, as likely to be able to furnish information on the question, that the Court will prepared to receive,... written statements, or to hear, at a public sitting to the held for the purpose, oral statements or both shall be permitted to comment on statements made by other states or organization...

4. States and organizations having presented written or oral statements or both shall be permitted to comment on the statement made by other States or organizations in the form, to the extent, and within the time-limits which the Court, or, should it not be sitting, the President, shall decide in each particular case...

The right to be thus heard of the 'non-parties' in the advisory proceedings seems more open comparing to the aforementioned Article 34 which stipulates "public international organization." The term 'international organization' laid down in Article 66 is not specified further by the Rule. Article 66 of the ICJ Statute is based on Article 66 of the revised PCIJ Statute of 1929 which also permitted international organizations to participate in advisory proceedings. Although the term of international organizations was not defined in the PCIJ Statute, some scholars at that time considered that the provision permitted only public organizations. ${ }^{72}$ However, the practice showed the opposite outcome. In 1922, the PCIJ gave three advisory opinions concerning the ILO as follows: (1) "Competence of the International Labour Organization; (2) Designation of the Workers' Delegate for the Netherland at the third session of the International Labour Conference; and (3) First Ordinary Session." 73 Various organizations submitted documents to the Court. 74 In each of the three cases, 75 the Courts decided "to hear, at the public sitting, the representatives of any Government and international organization

72 Shelton, supra note 4 , at 621.

73 Publication of the Permanent Court of International Justice (1922-1946) (ser. B): Collection of Advisory Opinions, available at http://www.icj-cij.org/pcij/series-b.php?1=9\&p2=2 (last visited on July 28, 2012)

74 Publication of the Permanent Court of International Justice (1922-1946) (ser. C): Acts and Documents relating Judgments and Advisory Opinions given by the Courts; for Documents relating to Advisory Opinions No. 1, available at http://www.icj-cij.org/pcij/serie_C/C_01/C_01_05_documents_Avis_No_1.pdf (last visited on Nov. 1, 2012). See Documents relating to Advisory Opinion No. 3, available at http://www.icj-cij.org/pcij/serie_C/C_01/C_01_07_ documents_Avis_No_3.pdf (last visited on July 28, 2012).

75 See Advisory Opinion No. 1, available at http://www.icj-cij.org/pcij/serie_B/B_02/Competence_OIT_Agriculture_ Avis_consultatif.pdf (last visited on Nov. 1, 2012). See also Advisory Opinion No. 3, available at http://www.icjcij.org/pcij/serie_E/Francais/E_08_fr.pdf (last visited on July 28, 2012) 
which... expressed a desire to be so heard." This statement reflected the Court's interpretation of the provision to cover non-governmental organizations. This view was adopted in later cases, as well.76

The early practice of the ICJ shows that NGOs were considered as international organization' within the meaning of Article 66 of the Statute. In its advisory proceedings in the International Status of South-West African case, 77 the Board of Directors of the International League of the Rights of Man (subsequently became International League of Human Rights after 1976) sent a communication to the Court asking permission to submit written and oral statements; the Court decided to allow the submission according to Article 66(2) of the ICJ Statute. However, the League's written statement has not been included in the proceedings for the reason that it was not submitted to the Court within the time-limit fixed by the Court.78 For the same reason, the League was also refused to participate in the oral proceedings.79

In 1970, when the United Nations Security Council requested the ICJ an advisory opinion on the Legal Consequence for States of the Continued Presence of South Africa in Namibia (South African case) notwithstanding Security Council's Resolution No. 276(1970), 80 the International League of the Right of Man, along with another NGO, also requested to be allowed to furnish written statement and to participate in the oral proceedings. This time, the Court did not allow these NGOs to accede to the Court proceedings, 81 considering that they were not 'international organization' within the sense of the Statute. 82 The Court's position on this issue can be seen as its implicit reconsideration on the status of NGOs under Article 66 of the Statute that was adopted earlier in the South-West African case in 1950.83

However, from the reading of the Rules of Court relating to advisory opinion, as adopted in 1978, it can be suggested that the Court would not bar NGOs to furnish information concerning the request since Article 105(1) of the ICJ Rules stipulates that: "Written statement submitted to the Court shall be communicated by the Registrar to any organizations which have submitted such statement." 84

76 Shelton, supra note 4, at 621-623. See also C. Chinkin, Third PARTIES In InTERnational LaW 226-227 (1993).

77 See International Status of South-West Africa, Advisory Opinion, 1950 I.C.J. 128 (July 11), available at, http://www.icj-cij.org/docket/files/10/8933.pdf (last visited on Oct. 21, 2012).

78 Id. at 346

79 Id. at $343-344$.

80 Legal consequence for States of the Continued Presence of South Africa in Namibia (South West Africa) notwithstanding Security Council Resolution 276 (1970), Advisory Opinion, 1971 I.C.J. 16 (June 21).

81 Id. at $639-640$.

82 See The Registrar's response to the American Committee on Africa, id. at 647.

83 Barthalomeusz, supra note 4, at 226. See also R. Clark, The International League for Human Rights and South West Africa 1947-1957: The Human Rights NGO as Catalyst in the International Legal Process, 3 HuM. RTs. Q. 101 (1981).

84 ICJ Statute art. 105(1). 
It seems that the term 'any organization' which is used in Article 105 appears to be broader than the term 'international organization' in Article 66 of the Statute encompassing all kind of organizations. However, the Court practice still confirms that such was the case.

In the advisory proceedings on Legality of the Use by a State of Nuclear Weapons in Armed Conflicts, many documents coming from the international civil society were sent to the Court and received by the Registrar. According to Jeremy J. Stone ${ }^{85}$ who was the former President of the Federation of American Scientists, the amicus brief by the Federation of American Scientists and the summery of which was published in the International Herald Tribunal, 86 was sent to the Court. The Court examined whether to accept the amicus brief as part of its records and finally decided not to accept an unsolicited one. The Registrar wrote to the New York Times, assuring the public in the following terms:

I would point out that, contrary to the impression that may have been given... the amicus brief has been received by the Court but has not been admitted as part of the record in those cases. It is, however, available to Member of the Court in their Library. The Court has received numerous documents, petitions and representations from non-governmental organizations, professional associations and other bodies that while they have no formal standing in the proceedings before it, wish to communicate their views on the subject matter of these important cases. The Court would like to make it clear that all such documents are given consistent treatment and that the Federation of American Scientists has not been accorded more favorable consideration than any other body. 87

These examples seem to demonstrate that even, in the advisory proceedings, the Court is not less reluctant to the amicus curiae submission by NGOs.

\section{Practice Directions of the ICJ}

The ICJ first adopted the Practice Direction in 2001 for the States appearing before it to use as standard additional to the Rule of Court.

Subsequent to the incidences that occurred in the two cases concerning the nuclear weapons, the Court's Practice Directions was amended in 2004. Practice Direction XII

86 Id. at 105-106. The author wrote that he had placed an article summarizing the amicus brief in The International Herald Tribune without indication of date of its publication.

87 E. Valencia-Ospina Court Clarification: Letter to the Editor, N.Y. Times, Nov. 15, 1995, available at http://www.nytimes.com/1995/11/15/opinion/15iht-edlet.t_21.html (last visited on July 28, 2012). 
newly adopted to confirm the Court's position previously adopted. 88 Practice Direction XII provides that:

1. Where an international non-governmental organization submits a written statement and/or document in an advisory opinion case on its own initiative, such statement and/or document is not to be considered as part of the case file.

2. Such statements and/or documents shall be treated as publication readily available and may accordingly be referred to by States and intergovernmental organizations presenting written and oral statements in the case in the same manner as publications in the public domain.

3. Written statements and/or documents submitted by international nongovernmental organizations will be placed in a designated location in the Peace Palace. All State as well as intergovernmental organizations presenting written or oral statements under Article 66 of the Statute will be informed as to the location where statements and/or documents submitted by international non-governmental organizations may be consulted.

Nothing can guarantee that the Court makes use of NGOs documents. Recently, in Arrest Warrant of 11 April 2000 case between Congo and Belgium, 89 the Amnesty International submitted a memorandum that served the function of an amicus curiae. 90 Belgium also produced and submitted this document to the Court in the form of a CDROM. The judges reportedly did not have facilities to read the CD-ROM. This document was referred to, however, by some judges. 91

The commitment by this Practice Direction XII to place NGOs' submission on their own initiative in the Peace Palace could be interpreted as the Court's openness to NGOs,92 comparing to its previous decisions. At the same time, however, it seems that the adoption of this Practice Direction XII also reflects a compromise between the categorical rejection and the possibility to formal access of NGOs to the ICJ proceedings. Thus, the submission by means of this Practice Direction may be considered as informal amicus curiae if the Court refers to it. Otherwise, these documents remain to be the same as any other information available to the public.

The provisions for amicus curiae and the practice of the ICJ concerning NGOs'

\footnotetext{
88 It is indicated on the ICJ website that: "Practice Directions involve no alteration to the Rules of court, but are additional hereto." They are the result of the Court's ongoing receive of its writing method, available at http://www.icj-cij.org/document/index.php?p1=4\&p2=4\&3=0 (last visited on July 28, 2012).

89 Arrest Warrant of 11 April 2000 (Congo v. Belg.), Judgment, 2002 I.C.J. 3 (Feb. 14).

90 AmNesty International, Study on UniverSal JURISDiCTion (AI Index: IOR 53/002-081/2001, Sept. 2001).

91 D. Zagorac, International Courts and Compliance Bodies: The Experience of Amnesty International, in Treves et al. (eds.), supra note 4 , at 15 .

92 Barthalomeusz, supra note 4, at 224.
} 
participation in its proceedings reveal that the Court initially begun with a permissive approach, but rapidly adopted a very restrictive position. The legal argument of this direction shift is that NGOs are neither public international organization nor international organization in the sense of the Rule of Court. In connection to the nonState actor submission of amicus curiae brief, there is another reason of the Court's rejection that was revealed by the Registrar; the reason is that the Court would be "unwilling to open the floodgates to what might be a vast amount of proffered assistance." 93

Up to now, the Court's practice shows that the International League of the Rights of Man has remained the only NGO that has been allowed to submit amicus curiae brief in the International Status of South-West African case. It is very unfortunate that this opportunity has not been fruitful for the reason of the procedural default.

\section{Legitimacy of NGOs' Participation in the ICJ Proceedings}

The application of rules concerning the participation of NGOs in the ICJ's proceedings and the adoption of the Practice Direction XII reflect the restrictive viewpoint towards NGOs' participation. They do not indicate any possibility to submit information to be regarded as formal submission or to intervene as experts. Some observations would be made in relation to the legitimacy of NGOs' participation in the Court proceedings.

\section{A. Attitude of the Court}

The participation of NGOs as amicus curiae in the ICJ's proceedings is very informal in character; it is thus difficult to evaluate the real influence of the action and contribution of NGOs, if any, on the content of the Court's decisions and opinions because NGOs' amicus curiae briefs are not accepted as official documents for the Court. Whenever the NGOs have submitted amicus curiae briefs containing elements of law it is difficult to know to what extent these briefs will influence judgments, because the Court's judgments and opinions do not contain the comprehensive references to the sources of documents used for its conclusions. Even if the contribution of the NGOs might have

See The Registrar's response to Professor Michael Reisman when he asked to the Court about the possibility for an individual to submit an amicus curiae brief in Namibia case proceeding. He argued that: "There is no explicit prohibition in the Rules of the Court for an interested group or individual to submit a brief by its own initiative." See Clark, supra note 66, at 119-120. 
influence it, the ICJ may appropriate the information in the briefs, as all other information gathered during the proceedings, to elaborate the Court's own argumentation.

There are, however, only certain indications that could be observed from judges' opinions. The question concerning the nuclear weapons generated a remarkable mobilization of international civil society, enough to bring this question to the ICJ's advisory proceedings. This resulted in two requests of advisory opinions to the ICJ on the legality of nuclear weapons emanating, respectively from the World Health Organization in 199394 and the United Nation General Assembly in 1994.95

In the Advisory Opinion on the Legality of the Threat or the Use of Nuclear Weapons, Judge Weeramantry wrote in his dissenting opinion that:

A multitude of organization, including several NGO's has also sent communications to the Court and submitted materials to it, and nearby two million signatures have been actually received by the court from various organization and individuals from around 25 counties. In addition, they have been other shipments of signatures so voluminous that the Court could not physically receive them and they have been lodged in often depositories. If these are also taken into account, the total number of signatures has been estimate by the Court's Archivist at over three million. 96

...though these organization and individuals have not made format submission to the Court they evidence a groundswell of global public opinion which is not without legal relevance....97

Judge Weeramanthy also recognized that this reflected the attitude of the international community towards nuclear weapons. This attitude was represented by not only the views of States concerning nuclear weapons, but also by the fact that "there is also a vast preponderance of public opinion across the globe," coming from various civil society organizations which strongly protested against nuclear weapons. 98 
However, not all judges adopted the same view. In the same advisory opinion, Judge Oda, giving several reasons dissenting from the majority of Judges' decision to comply with the General Assembly's request for the reason of the inadequacy of the question, stated that:

8. (Non-governmental organization.) I would also point to another factor. The idea behind the resolution whereby the General Assembly (also the WHO) requested advisory opinions had previously been advanced by a handful of non-governmental organizations (NGOs) which initiated a campaign for the total prohibition of nuclear weapons...99

Judge Oda, citing various statements from the NGOs which supported the attempt to get an advisory opinion from the ICJ, concluded that:

This gives the impression that the request for an advisory opinion which was made by the General Assembly in 1994 originated in ideas developed by some NGOs. 100

Judge Guillaume appeared clearly reluctant regarding the NGO's involvement in such circumstance as well. He expressed his view in his separate opinion that:

[t] he Court could have considered declining to respond to the request for an advisory opinion. This solution would have found some justification in the very circumstances of the seisin. The opinion requested by the General Assembly of United Nations (like indeed the one requested by an association called International Association of Lawyers Against Nuclear Arms (IALANA), which in conjunction with various other groups lunched in 1992 a project entitled "Would Court Project" in order to obtain from the Court a proclamation of the illegality of the threat or use of nuclear weapons. These associations worked very intensively to secure the adoption of the resolutions referring the question to the Court and to induce States hostile referring to nuclear weapons to appear before the Court. Indeed, the Court and the judges received thousands of letters inspired by these groups, appealing both to the Members' conscience and to the public conscience.

I am sure that the pressure brought to bear in this way did not influence the Court's deliberations, but I wondered whether, in such circumstances, the requests for opinions could still be regarded as coming from the Assemblies which had adopted them or whether, piercing the veil, the Court should not have dismissed them as inadmissible. However, I dare to hope that Governments and intergovernmental institutions still retain sufficient independence of decision to resist the powerful

99 Id. at Dissenting Opinion of Judge Oda, at 335.

100 Id. at 336. 
pressure groups which besiege them today with the support of mass media. I also note that none of States which appeared before the Court raised such an objection. In the circumstances I did not believe the Court should uphold it proprio motu. 101

In the case concerning the Arrest Warrant of 11 April 2000 between Congo and Belgium, Judge Van Den Wyngaert (ad hoc judge) referred to in her dissenting opinion various NGOs' studies including Amnesty International. She expressed her opinion concerning the value and impact of these works as follows:

In legal doctrine, there is a plethora of recent scholar writings on this subject. Major scholarly organizations...have made statement on this issue. Advocacy organizations, such as Amnesty International, Avocats sans Frontières, Human Rights Watch, The International Commission of Jurists, have taken clear position on the subject on international accountability. This may be seen as opinion of civil society, an opinion that cannot be completely discounted in the formation of customary international law today. In several cases, civil society organizations have set in motion a process that ripened into international convention...

The Court fails to acknowledge this development, and does not discuss the relevant sources. 102

Regarding the use of documents, even though all the documents submitted to the Court are not considered as part of the case file, they are made available to the judges for consultation. It depends, thus, on the discretion of the Court or of the individual judges to find it necessary or not to consult these documents. In the Lotus case, the PCIJ adjudicated:

observes that in the fulfillment of its task,...it has not confined itself to a consideration of the arguments put forward, but has include in its researches all precedents teachings and facts to which it had access... 103

The ICJ reaffirmed this position in the Nicaragua case. In this case by stating that:

The principle jura novit curia signifies that the Court is not solely dependent on the argument of the parties before it with respect to the applicable law" 104 and "As to the facts of the case, in principle the Court is not bound to confine its consideration to the material formally submitted to it...105

101 Id. Separate Opinion of Judge Guillaume, at 287-288.

102 Supra note 89. Dissenting opinion of Judge Van Den Wyngaert, at 154-155, ๆ 27-28.

103 The Case of the S.S. 'Lotus' (Fra. v. Tur.), 1927 P.C.I.J. (ser. A) No. 10, at 31.

104 Military and Paramilitary Activities (Nicar. v. U.S.), 1986 I.C.J. 29 (June 27).

105 Id. $\uparrow 30$. 
Consequently, the Court may make use of the documents furnished to it.106 Such rare examples demonstrate that there are dispersed opinions among the judges. In addition, the available examples are insufficient to conclude that, despite the formal barriers for NGOs to participate in the Court proceedings, civil society opinions could be de facto significantly taken into consideration by the other judges during the Court proceedings. It may be risky to assume that this might not appear to be the case as, apart from the statements mentioned above, the reference to NGOs' briefs in separate and dissenting opinions is, it seems, unnoticed. Moreover, the principle jura novit curia was reaffirmed in the Nicaragua case i.e. the application seems to have its place in the ICJ proceedings when the documents are provided by State parties.

\section{B. Participation in the Defense of Universal Interest}

It has been observed that NGOs' efforts to involve in the ICJ proceedings concern the issues related to the legal questions of human rights, environmental law and humanitarian law. While each of these three legal arena seems different from each other, they all share common characteristic, i.e., protecting the universal interest. The ultimate goal of these laws is not to protect the interest of the States or the individuals, but the survival of humanity. In various occasions this particular characteristic was emphasized by scholars and international jurists. The legal obligations of these matters are the one which binds States towards the international community. 107 This obligation 108 represents the ultimate stage of the mutually supportive cooperation. ${ }^{109}$ It is the common interest of the international community which underlines this type of obligation. The common interest of the international community has a universal value. Universality is often defined as values shared by all men.110 Therefore, to advocate universal interest has the only real purpose. That is to ensure the survival of mankind.111

106 Id. 13 . In the Nicaragua case, the ICJ took into account a publication of U.S. Department of State which has been sent to an official of the Registry to be made available to anyone at the Court interested in the subject, and despite Nicaragua's objection stating that: "It may, within limits, make use of information in such a publication."

107 See e.g., Barcelona Traction Light and Power Company (Belg. v. Spain), Judgment, 1970 I.C.J. 32, ๆ 33-34 (Feb. 5). See also Legality of Threat of the Use of Nuclear Weapons (1995), Advisory Opinion, 1966 I.C.J. 241-242, ๆ 29 (July 8); supra note 66, at 41, ๆ 53 (Sept. 25).

108 J. Crawford, The International Law Commission's ARticles on States Responsibility, Introduction, Text and COMmENTARIES 41-42, 276-280 (2002).

109 P.-M. Dupuy, Humanité, Communauté et Efficacité du Droit, in Humanite et Droit InTERnational; Melanges OfFERTS A RENE-JEAn Dupuy 138 (A. Pédone ed., 1991).

110 J. Salmon, Dictionnaire de Droit International Public 119 (2001).

111 C. Tomuschat, International Law: Ensuring the Survival of Mankind on the Eve of a New Centaury, General Course on Public International Law, 128 RCADI, 9-438 (1999). 
It is undeniable that the notion of the 'international community' is essentially the "international community of States" as evidences by various legal provisions.112 The ICJ in Barcelona Traction case also stressed that erga omnes is "obligation of a State towards the international community as a whole... all States can be held to have a legal interest in there protection." 113

However, Professor Crawford argued that: "If the phrase 'the international community of States as a whole' is intended as exclusive (i.e. as excluding non-states from the process of law-formation in the field of peremptory obligations), it no longer reflects the reality of the world." 114 'States' remain central to the process of international law making and its enforcement; it is axiomatic that every State is as such a member of the international community. Notwithstanding, the international community includes entities in addition to States and the role that they play can be legally significant.115 For this reason the concept of the international community needs to be inclusive and openended.116

If the NSAs are regarded as a crucial part of the international community, then NGOs are in-part justified in defending and speaking for the common interest of the international community, not only in the law-making process, but also in judicial proceedings as confirmed by various international judicial bodies.

If NGOs are allowed to participate in ICJ proceedings, their contributions would help the judges in shaping international law. In this respect, NGOs would become a true partner in using international law to protect the collective interests. Their contributions would not be limited to the specific case in which they are involved because the Court's decision, despite the principle of lex judicata for the contentious case and the nonbinding effect for the advisory case, constitutes an authoritative precedent influencing the attitude of States. 117

\section{Participation: Democracy in the ICJ's Proceedings}

Under international law, States are the only actors that can participate in international proceedings. This principle excludes large groups of NSAs from being represented internationally. In spite of the State-centric principle, States are not the sole actors in the

\footnotetext{
112 E.g., The Vienna Convention on the Law of Treaty art. 53. It reads: "For the purposes of the present Convention, a peremptory norm of general international law is a norm accepted and recognized by the international community of States a Whole."

113 Belg. v. Spain, supra note 107, at 33.

114 J. Crawford, Responsibility to the International Community as a Whole, 8 IND. J. GLoBAL LeGAL STUD. 313 (2001).

115 Id. at 314 .

116 Id. at 315.

117 Shigeru Oda, The International Court of Justice Viewed from the Bench, 244 RCADI 78-79 (1993).
} 
international community and more actors are allowed to participate in international governance. 118 Fairness and openness are the most important conditions for democratizing international law and institutions. ${ }^{119}$ It may also be argued that more representation by NSAs would serve to reduce the deficit in international law-making and implementation. 120

International law is no longer a closed norm and not simply a relationship between sovereign powers. 121 The amicus curiae is a vehicle by means of which the concerns of international civil society can be expressed when the status of a party to a proceedings is limited.

It has been observed by major international judicial bodies that the 'democratization' of international judicial proceedings is progressing. Regional and universal judicial bodies, except in the case of the ITLOS, are open more or less for allowing NSA participation. However, the ICJ has taken the opposite approach.

The reluctance of the ICJ to allow NGO participation does not seem to dissuade the movement of civil society to assert the legitimacy of its rights. The legality of nuclear weapons means something in terms of international public opinion. Civil society is, in this exceptional case, able to put pressure on States and international organizations to set the ICJ in motion. In this particular case, civil society may in effect replace the State as the main actor in the ICJ proceedings. If this step is considered an abuse of process well established in international law for the ICJ proceedings, taking into account the allocation of rights in international relations, 122 one wonders whether the condition to recognize the right of participation in ICJ proceedings is in accordance with the changing structure of international law in increasing the role of the NSAs. 123

118 The Secretary-General, Agenda for Development, 9 59, delivered to the General Assembly. See U.N. Doc. A/48/935 (May. 6, 1994) available at http://www.un.org/ga/search/view_doc.asp?symbol=A/48/935.

119 According to Professor Thomas Frank, "Fairness discourse requires fairness in the selection of participants. At present the term 'global discourse' suggests a conversation between nations, that limited view, however, is wrong...In addition, and centrally, the mental model's wrongness lies in its unfairness.” See T. Frank, The PrincIPLE OF FaIRNESS IN INTERNATIONAL LAW AND INSTTTUTIONS 484 (1995).

120 Karsten Nowrot, Legal Consequences of Globalization: The Status of Non-Governmental Organizations under International Law, 6 InD. J. GLoBAL LeGal STUD. 600-601 (1999). See also A. Clark, Non-Governmental Organizations and Their Influence on International Society, 48 J. INT'L AFF. 523 (1998). According to Clark, the presence of NGOs in the environment of international law will not remove the role of the State, since States and the intergovernmental are likely to remain a central point for policy-making arena and coordinating action on international issues such as human rights and environment. But this does not mean that NGOs would not be influential. Their contribution to the international arena regulated by the States and the intergovernmental units, Clark contends, "can turn them into organizational avenues for citizens as well as states on pressing global issues."

121 H. Ascensio, L' Amicus Curiae devant les Juridictions Internationales, 105 RGDIP 900 (2001).

122 N. Leroux, La Contribution des O.N.G. à la Promotion et à la Garantie de l'Etat de Droit, in L'Etat de Droit en Droit International, Colloque de BruXelles, Societe FrançAISE POUR LE DrotT InTERNATIONAL 357-358 (2009).

123 R. Higgins, The Reformation in International Law, in LAW, Society and Economy: Centenary EssaYs FoR the LoNdon School of Economic ANd Political ScIEnce 1895-1995, 211-215 (R. Rawlings ed., 1997) 
Allowing NGOs to participate in ICJ proceedings does not mean that NGOs would become party in contentious proceedings or would be granted a right to request an advisory opinion. If the Court allows NGOs to submit amicus briefs, it is likely that many additional briefs would be filed. However, all of these additional briefs should be accepted as part of the official file. The Court has discretionary power to consider whether any of the briefs are useful and can help the Court administer justice.124

\section{Administration of Justice}

The principles of impartiality and neutrality are fundamental in the judicial process. 125 The idea of a neutral and impartial judge reflects two significant aspects of the identity of a judge: being neutral and detached from all parties while at the same time being cognizant of all issues in the case. These conditions are universal and essential for international judges to perform their duties as neutral arbiters. Moreover, contemporary international justice suggests that these principles mean as reassembling of the subtle balance of powers and practices between justice, politics and ethics. 126

NGO activities aim to influence its emergence, content, impact as well as implementation in international legal forum. The process to this objective is far from being purely 'legal.' Instead, it is apparently 'political.' The process of reforming international law 127 involves mobilizing State and inter-governmental organizations. NGO movements have reached the ICJ, e.g., in the context of nuclear weapons; some judges have expressed serious concern. However, the political aspect of the issues

124 One of the reasons that the Court authorizes or invites a third party to intervene in the case is for the proper administration for justice. The expression "proper administration of justice" or other expressions having the same meaning have been found in many articles of rules of the courts by which the courts allow the third party to participate in the Courts' proceedings. E.g., The European Convention on Human Rights art. 36(2). It reads: "The President of the Court may, in the interest of the proper administration of justice, invite any High Contracting Party which is not party to the proceedings or any person concerned who is not the applicant to submit written comments or take part in hearings." [Emphasis added] Article 74 of both the Rule of Procedure and Evidence of the ICTR and the Rules of Procedure and Evidence of the ICTY states that: "A Chamber may, if it considers it desirable for the proper determination of the case, invite or grant leave to a State, organization or person to appear before it and make submission on any issue specified by the Chamber." [Emphasize added] Article 103 (1) of the Rules of Procedure and Evidence of the ICC states that: "At any stage of the proceedings, a Chamber may, if it considers it desirable for the proper determination of the case, invite or grant leave to a State, organization or person to submit, in writing or orally, any observation on any issue that the Chamber deems appropriate." [Emphasis added]

125 G. Timsit, Les Figures du Jugement 52 (1993). See also P. -M. Dupuy, Le Juge et la Règle Gé né rale, 93 RGDIP 570597 (1989).

126 E. Jouannet, Actualité des Questions d'Indé pendance et d'Impartialité des Juridictions Internationales : La Considé ration des Tiers Pouvoir International? in H. FraBri \& J.-M. SoraL, INDEPENDANCE ET IMPARTIALITE des JUGES INTERNATIONAUX 271-272 (2010).

127 Higgins, supra note 123. 
brought before the Court is not present only in the cases in which NGOs are involved. It is no longer necessary to show that the referrals to the ICJ in contentious and advisory cases have not only legal implications but also political aspects. The political nature of NGO activities does not necessary implies that the Court has to exercise its judicial power in accordance with any political pressure. In exercising its function, the Court must remain independent from external powers just as a court must remain neutral from external pressure.128 If the ICJ cannot directly oppose political pressure, the Court can nevertheless control it since each international judge is in sum the depositary of the whole judicial function. 129

One could argue that NGO should not file amicus briefs in contentious cases because the consensual character of jurisdiction in such cases implies that access to the Court is restricted.130 Actually, the parties' autonomy represents indisputably an important element which has to be protected in order to maintain the confidence of State parties before the Court. This does not imply, however, that the Court should not be concerned about broader aspects of the case beyond the parties' dispute, because the Court must take into account not only the interests of the parties, but also administering justice. It is also disputable that amicus briefs from NGOs would risk undermining party autonomy. Besides, permitting NGOs to present an amicus brief and eventually considering it in the interests of the proper administration of the international justice is not incompatible with the Statute and the Rules of the ICJ. In this regard, Professor Shabtai Rosenne wrote that the Court had power to prevent any possible abuse of process, and giving such opportunity would increase the Court's general standing and prestige.131

Another obstacle to NGO participation is the restrictive wording used in the Statute and Rules of the Court and the condition fixed by Practice Direction XII (2). It has been suggested that the preferable option is to amend Rule 69(4), redefining the term "public international organization" to mean "an international organization composed of states or a non-governmental organization holding consultative status with the United Nations." 132 However, Practice Direction XII (2) still bars amicus briefs that NGOs submit on their own initiative to be officially considered by the Court. Thus, this provision is to be considered an amendment, as well.133

\footnotetext{
128 Jouannet, supra note 126 , at 277.

129 L. Condorelli, Juridictio et (Dé s)ordre Judiciaire en Droit International: Quelques Remarques au Sujet de l'Arré $t$ du 2 Octobre 1995 de la Chambre d'Appel du Tribunal Pé nal International pour l'ex-Yougoslavie dans l'Affaire Tadic, in DRoIT ET Justice 28 (Mélanges en Honneur de Nicolas Valticos ed.1999).

130 Ranjeva, supra note 7 , at 50.

$131 \mathrm{~S}$. Rosenne, Reflection on the Position of the Individual in Inter-States litigation in the International Court of Justice, in International Arbitration: Liber Amicorum for Martin Domke 244 (P. Sanders ed., 1957).

132 Shelton, supra note 4 , at 642.

133 Id.
} 
If the Court allows amicus briefs from NGOs, it is crucial to "screen the candidates," considering the unique attributes of the ICJ that may require more restriction in granting an amicus curiae status to an NGO.134 It is clear that not all NGOs deserve to be representative of the civil society; 135 some are self-appointed and single issue-oriented. They are not often accountable to people on whose behalf they claim to represent. For these reasons, some criteria should be considered such as the role of amicus of the Court. 136

When an NGO accesses ICJ proceedings as amicus curiae, their ability to assist the ICJ should be evaluated in terms of their motivations, specialization and transparency in their management.137 It is recommended to establish a renewable list of the accredited NGOs to submit an amicus briefs as it has been made in many regional courts. Additionally, the ICJ should create a set of objective criteria for the transparency of its choice. To protect the collective interest of the international community, the legitimacy of NGOs to defend the collective interest lies in their particular vocation. To defend a collective interest, this mission should be entrusted only to those who have demonstrated a track record of professionalism. 138

In addition, the relevance of the argument in the amicus brief is a must be assessed. In the Chernobyl case, 139 the European Court of Justice privileged the substantive issue rather than the application of the formal requirement of the treaty in permitting the amicus curiae. 140

It cannot be overlooked that accepting NGO amicus briefs will increase the Court's workload. The Court should open its door to NGOs because of the benefit they can provide.141 Thus, NGOs must submit briefs that satisfy the administration of justice. It is not only the quality of the content that is important, but the cooperation among NGOs is also necessary for a more streamlined process in order to avoid duplication and waste of resources. 142

It would be in the interest of the ICJ to give accesses for NGOs to participate in Court proceedings, as either an amicus curiae or expert. Their information could provide

\footnotetext{
134 Id. at 627.

135 Lindblom, supra note 1, at 525.

136 Id.

137 Soumy, supra note 4 , at 361 .

138 Id. at 389-340.

139 European Parliament v. Council (Chernobyl) Case, C-70/88[1990] ECR I-2041.

140 A. Cygan, Protecting the Interests of Civil Society in Community Decision-Making-The limits of Art.230 EC, 52 INT'L CoMP. L. Q. 995-1012 (2003).

141 Shelton, supra note 4, at 618.

142 E. Rebesti \& L. Vierucci, A Legal Status for NGOs in Contemporary International Law?, available at http://www.esilsedi.eu/fichiers/en/VierucciRebasti_971.pdf (last visited on July 28, 2012).
} 
relevant views on the issues concerning common value. Increasing public participation may serve the ICJ best by ensuring that its opinions are based upon the fullest available information and reflect consideration of the public interest, as well as the desires and concerns of litigants. 143

\section{Conclusion}

The NGOs' participation in the various international judicial bodies would show that the international civil society can make contributions to the judicial decision-making process. Participating in international proceedings as a third-party is remarkable as either an amicus curiae or expert, particularly, in the circumstance where the protection of collective interests is at stake. Even today, legal texts and Court practice have a negative outlook on the role of NGOs participating in contentious and advisory proceedings. This exclusion is based on considerations of expediency rather than law.

Because NGOs are representatives of civil society, their participation as amicus curiae in ICJ proceedings would improve communication between the Court and the international community. Unfortunately, the status quo of the ICJ's Statute, Rules and Practice Directions indicate otherwise. If NGO amicus briefs submitted on their own initiative were officially considered, the Court could safeguard the rights of the parties or international organizations to each case more efficiently. [Emphasis added]

It is also important for NGOs to demonstrate that their request to submit leave is relevant as it provides the ICJ with valuable elements of the real global justice. Establishing trust between NGOs and the ICJ will be helpful to reduce the setbacks the Court experienced in the Nuclear Test cases.

143 Shelton, supra note 4, at 625. 